\title{
GEOLOGY AND MINERAL RESOURCE POTENTIAL OF THE GRAHAM CREEK ROADLESS AREA, ANGELINA AND JASPER COUNTIES, TEXAS
}

\author{
By \\ B. B. Houser, U.S. Geological Survey \\ and \\ George S. Ryan, U.S. Bureau of Mines
}

STUDIES RELATED $₫$ WILDERNESS

Under the provisions of the Wilderness Act (Public Law 88-577, September 3, 1964) and related acts, the U.S. Geological Survey and the U.S. Bureau of Mines have been conducting mineral surveys of wilderness and primitive areas. Areas officially designated as "wilderness," "wild," or "canoe" when the act was passed were incorporated into the National Wilderness Preservation System, and some of them are presently being studied. The act provided that areas under consideration for wilderness designation should be studied for suitability for incorporation into the Wilderness System. The mineral surveys constitute one aspect of the suitability studies. The act directs that the results of such surveys are to be made available to the public and be submitted to the President and the Congress. This report discusses the results of geological and mineral surveys of the Graham Creek Roadless Area (08021), Angelina National Forest, Angelina and Jasper Counties, Texas. The area was classified as a further planning area during the Second Roadless Area Review and Evaluation (RARE II) by the U.S. Forest Service, January 1979.

\section{MINERAL RESOURCE POTENTLAL SUMMARY STATEMENT}

Geologic and geochemical investigations have been conducted to evaluate the mineral resource potential of the Graham Creek Roadless Area, Angelina and Jasper Counties, Tex. The roadless area lies within the western Gulf of Mexico Coastal Plain and is underlain by Eocene, Oligocene(?), and Miocene semiconsolidated clastic sediments. Ninety percent of the mineral rights to land within the roadless area are privately owned.

The area has moderate to high potential for oil and gas on the basis of the regional setting and the presence of nearby producing fields. Kaolinite and smectite clay and general-use sand are present in the area. These conclusions are based on surface and shallow subsurface geologic examination, radiometric survey, and geochemical and mineralogic study of subsurface auger samples.

\section{INTRODUCTION}

Clay and sand have been quarried from two pits in the eastern part of the roadless area. Sand and sandstone for use as road metal are presently being quarried just outside the eastern boundary of the area. There is an abandoned clay pit south of the south-central boundary of the area, and there are numerous clay pits, both abandoned and active as near as $1.5 \mathrm{mi}$ west of the area.

These are no producing oil or gas wells within the area. One dry hole has been drilled in the area, and five dry holes have been drilled within $1 \mathrm{mi}$ of the area. A well drilled between the area and the Neches River apparently produced oil but is now abandoned. A small amount of natural gas bubbles up through the water that flows out of the casing of the abandoned well. Seismic exploration continues in and around the area.

The geologic mapping, shallow drilling, geochemical sampling, and radiometric surveys of this study were conducted in April 1981 and January to March 1982.

\section{Area description}

The Graham Creek Roadless Area comprises 7,766 acres in the Angelina National Forest in Angelina and Jasper Counties, Tex. (fig. 1). Topographically, the area can be divided into three parts. The southwestern part consists of flood plains and terraces of Graham Creek and the Neches River and ranges from 90 to $120 \mathrm{ft}$ in altitude. The central part is characterized by rolling hills and occasional sandstone ledges. The altitude is as much as $300 \mathrm{ft}$. The northern part of the area is relatively flat, ranging in altitude from about 130 to $240 \mathrm{ft}$. Drainage consists of perennial and intermittent streams flowing in a southerly direction to the Neches River. The climate is humid subtropical with an annual precipitation of about 51 in. and a mean annual temperature of about $67^{\circ} \mathrm{F}$. The area supports the vegetation of the pine woods belt of the forested Coastal Plain. 


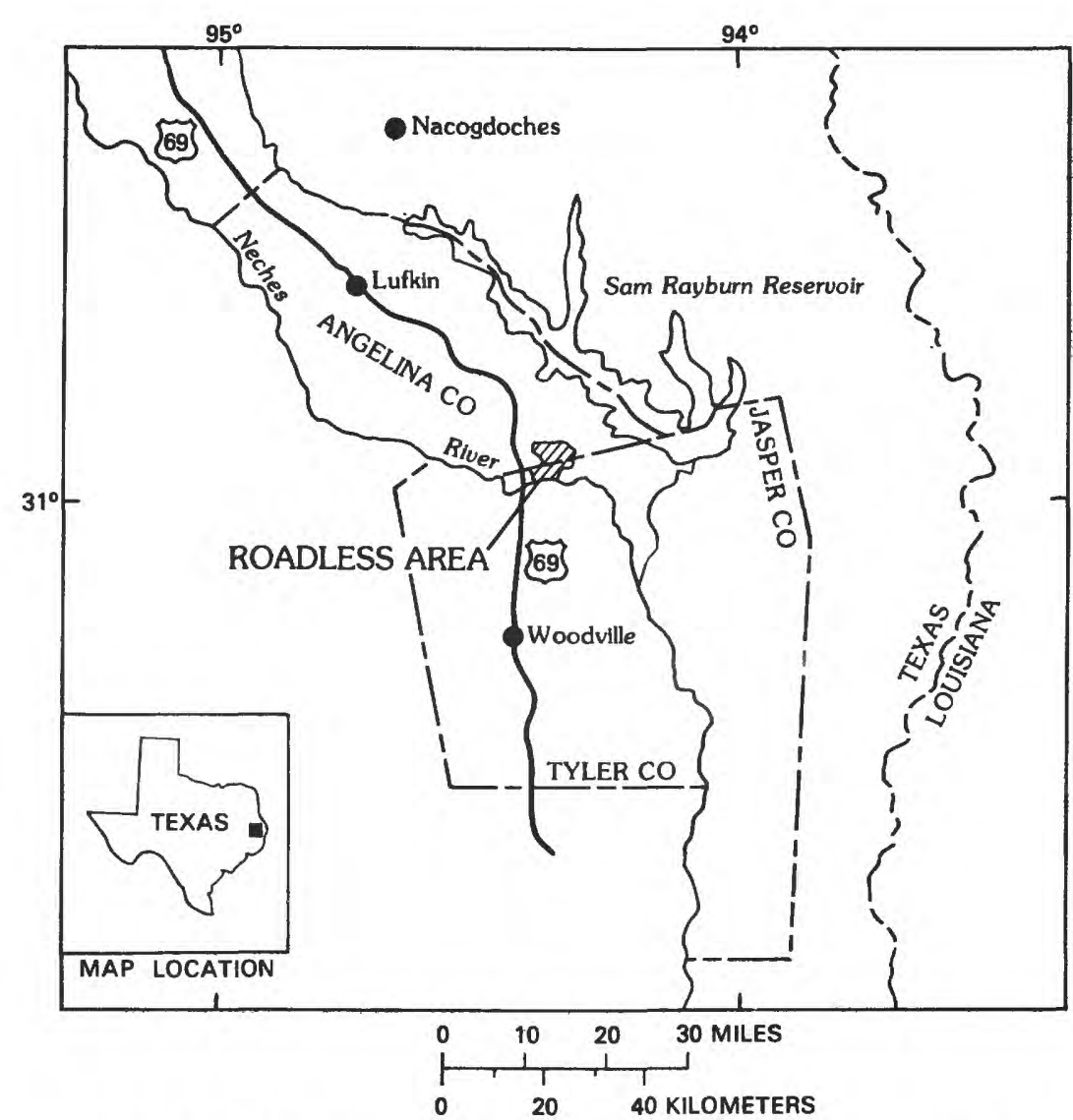

Figure 1.-Index map showing location of the Graham Creek Roadless Area (08021), Angelina and Jasper Counties, Texas. 
Access to the periphery of the area is provided by the Neches River and by U.S. Forest Service roads 302,328 , and 338. Interior access is provided by U.S. Forest Service roads 303-2, 309, 314, 338, 321, and 330. In three cases, in the southern part of the area, access to privately owned land outside the area is by dirt roads across the Graham Creek Roadless Area.

U.S. Forest Service records indicate that 90 percent of the mineral rights of the Graham Creek Roadless Area are privately held. Permits for seismic exploration surveys in and around the area are issued routinely.

\section{Previous investigations}

The roadless area has been included in several reports of regional scope on mineral and energy resources. Angelina and Jasper Counties are included in the survey of rock and mineral resources of East Texas by Fisher and others (1965). Under the National Uranium Resource Evaluation (NURE) program, a reconnaissance geochemical survey for uranium was made of the Palestine $1^{\circ} \times 2^{\circ}$ quadrangle, which includes the Graham Creek Roadless Area (U.S. Department of Energy, 1979). Dickinson (1976) discussed the potential for uranium in the Gulf Coastal Plain of Texas. The potential for uranium mineralization of specific formations that crop out within the roadless area was evaluated by Galloway (1977), Arfele (1980), and Ledger (1981). The ball clay and bentonite resources of the central and western Gulf Coastal Plain were reviewed in a reconnaissance study by J. W. Hosterman (written commun., 1982). Lignite resources in the National Forests of Texas have been evaluated by Garner and others (1978); lignite resources in Texas as a whole have been evaluated by Kaiser and others (1980). Information on oil and gas production, reserves, and potential can be found in Cram (1971), Peppard-Souders and Associates (1981, 1982), St. Clair and others (1976), International Oil Scouts Association (1977), American Petroleum Institute, American Gas Association, and Canadian Petroleum Association (1980), and The Railroad Commission of Texas (1981).

\section{Present investigation}

Geologic and geochemical investigations have been conducted to evaluate the mineral resource potential of the roadless area. The U.S. Bureau of Mines investigation included a radiometric survey and analysis of surface sediment samples for uranium. The U.S. Geological Survey conducted geologic and geochemical surveys of the region that included drilling and collecting samples from 12 auger holes (fig. 2), ranging from 17 to $107 \mathrm{ft}$ in depth, for stratigraphic and geochemical analyses.

The oil and gas resource potential of the area was evaluated by Gordon L. Dolton of the U.S. Geological Survey, using readily available data only.

\section{GEOLOGY}

The roadless area is in the north-central part of the greater western Gulf basin (Houston Embayment), which is filled with a thick sequence of offlapping sedimentary prisms of Cenozoic clastic rocks. This sequence rests upon Cretaceous and Jurassic sandstones and carbonates and the Jurassic Louann Salt. The area was mapped previously at a scale of $1: 250,000$ as part of the Palestine $1^{\circ} \times 2^{\circ}$ quadrangle of the Geologic Atlas of Texas (Barnes, 1968).

Quaternary alluvium in the Graham Creek Roadless Area is underlain by Eocene through early(?) Miocene semiconsolidated clastic sediments. The oldest units present in the area are the upper Eocene Manning and Whitsett Formations, both in the Jackson Group. These units are part of the Fayette delta system described by Fisher and others (1970).

The Manning and Whitsett Formations are lithologically similar, consisting chiefly of darkgreenish-gray (unweathered color), stiff, silty clay with fine-grained sand and silt laminae. Except for a 45-ft-thick interval in the Manning Formation, which contains abundant thin-walled pelecypod shells and was penetrated in auger hole 55, the units are unfossiliferous. Volcaniclastic materials are present in wuth units. In the Manning Formation, a 1- to 2-ftthick bed of very pure cream-colored smectite, inferred to be a volcanic ash layer, was penetrated at a depth of 15-17 ft in auger hole 56. A 15-ft-thick sequence of tuffaceous thinly bedded silt, possibly a lacustrine deposit, $4 \mathrm{ft}$ below the top of the Whitsett Formation, is exposed in the banks of a small tributary to the Neches River just south of the study area (locality 13-ZAV). The Whitsett contains numerous beds of lignitic silt and clay 1-2 ft thick. Trough crossbedded Whitsett silty sandstone containing plant fragments is exposed in the Neches River at low water.

The contact between the Manning Formation and the overlying Whitsett is apparently gradational and could not be recognized in the auger holes. Therefore, the Manning-Whitsett contact was modified from Barnes (1968), assuming a thickness of about $60 \mathrm{ft}$ for the Whitsett Formation. An erosional unconformity separates the Eocene Whitsett Formation from the overlying upper Oligocene(?)-Miocene Catahoula Formation.

The depositional system of the Catahoula Formation in East Texas is named the Chita-Corrigan fluvial system for the Chita and Corrigan sand units in the lower part of the formation. Fine-grained sandy siltstone and tuffaceous claystone in the upper part of the Catahoula locally is termed the Onalaska clay. Investigations of the Catahoula that include the roadless area are those of Scheldt (1976), Galloway (1977), and Ledger (1981). In adjacent areas, the Catahoula has been investigated by McBride and others (1968) and by Paine and Meyerhoff (1968).

The sand units of the lower part of the Catahoula Formation underlie the central hills of the Graham Creek Roadless Area and consist of as much as $100 \mathrm{ft}$ of clean to slightly muddy or clayey, fine- to coarsegrained, crossbedded sand. The basal 10-20 ft of sand commonly contains pebble conglomerate lenses, kaolinite clay balls and rip-up clasts, and pieces of opalized palm wood ranging in size from a few millimeters to the size of logs. None of the sand encountered in the auger holes was cemented; however, extremely hard opal-cemented sandstone is locally common in outcrops. The local and variable extent of the pods of opal-cemented sandstone is well exposed in the gravel pit between the eastern boundary of the area and Big Creek. 


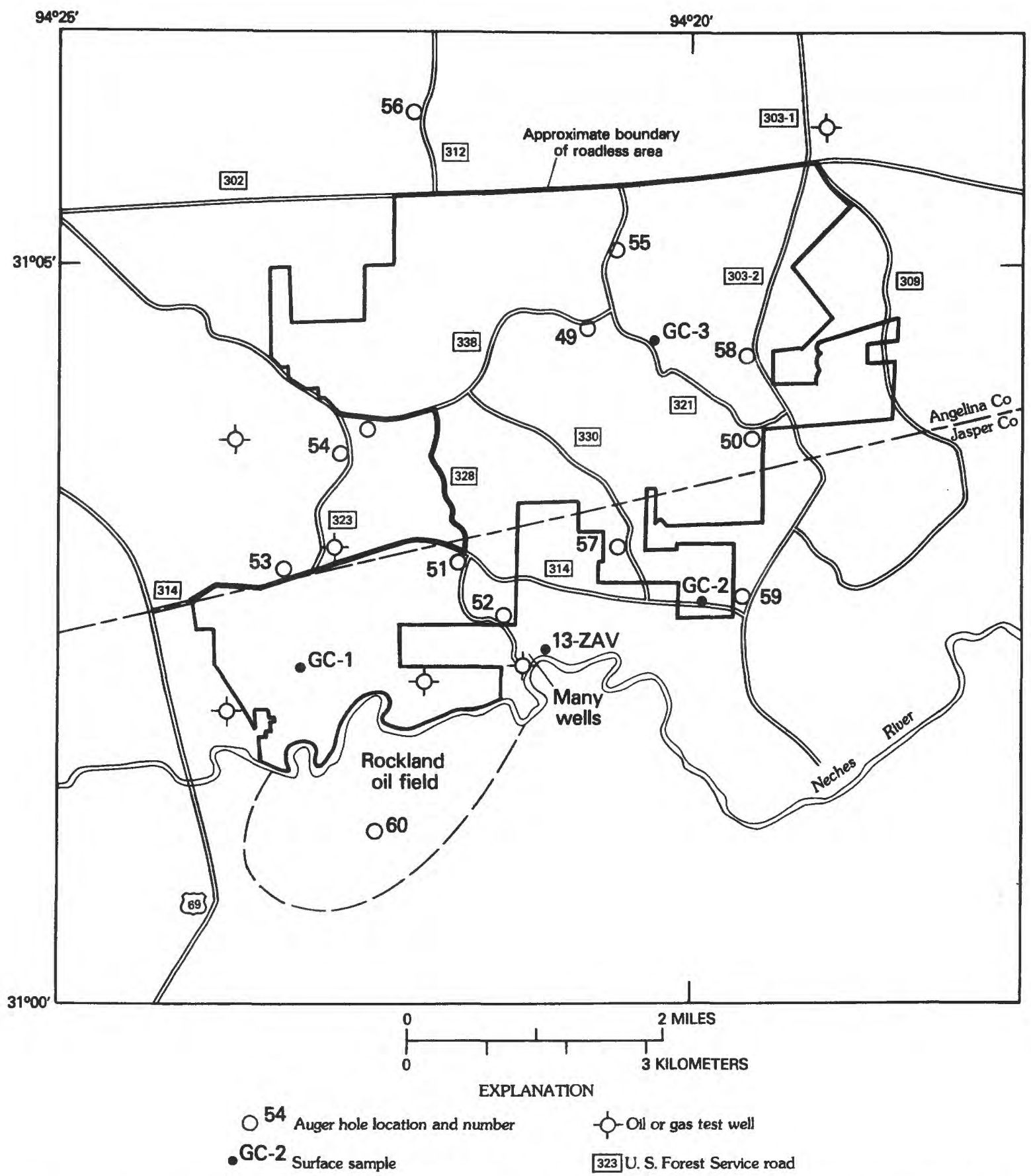

Figure 2.-Map of the Graham Creek Roadless Area showing localities of auger-hole and surface samples, and oil and gas test wells. 
Throughout the roadless area, the contact of the Whitsett and Catahoula was placed at the base of the sand and top of the silt and clay. In the south and southeast part of the area, however, at least the upper 18-20 ft of clayey silt (auger hole 59 and locality 13ZAV) perhaps should be included in the Catahoula Formation. The sediment in question in auger hole 59 is light-gray, massively bedded, kaolinitic mudstone. It has the appearance of a mudflow or loess deposit, but it may represent flood plain or lacustrine deposition. At locality 13-ZAV, the questionable interval includes the $15 \mathrm{ft}$ of tuffaceous lacustrine silt described previously as part of the Whitsett Formation.

Quaternary alluvium is present in the flood plains of Graham Creek, Big Creek, and the Neches River. The contacts were drawn from aerial photographs. The alluvium of Graham Creek consists of fine-grained sand and sandy silt. Alluvium along the Neches River consists chiefly of clean, medium- to very coarse grained sand containing pebbly sand lenses.

\section{Structure}

Regionally, the Tertiary rock units strike about N. $75^{\circ}$ E. and dip gently $\left(1 / 2^{\circ}-2^{\circ}\right)$ to the southeast as shown by the map pattern of these units on the Palestine $1^{\circ} \times 2^{\circ}$ quadrangle geologic map (Barnes, 1968). Within the roadless area, however, contours drawn on the erosional unconformity separating the Whitsett and Catahoula Formations indicate that part of this surface has the shape of one-third of a dome (fig. 3A). The available data are not sufficient to determine if this is an erosional dome or a structural dome. If structural, two possible causes are an underlying salt dome or a perturbation of regional strike by some unidentified structural element(s). Regional structural cross sections give no indication of dip inflections or reversals, either across the area or across adjacent areas along strike (Dodge and Posey, 1981). The drainage pattern of the streams in and around the area is very similar to the pattern developed by streams draining the area overlying the Oakwood salt dome in eastern Texas (fig. 3B; Collins and others, 1981). However, this drainage pattern could also be a result of differential permeability and erodibility of the lithologic units of the area.

\section{ASSESSMENT OF MINERAL RESOURCE POTENTIAL}

\section{Oil and gas}

The Graham Creek Roadless Area has moderate to high resource potential for oil and gas (fig. 4). Data show a history of scattered, mostly very shallow, exploration drilling in and around the area, especially at its southern and western edges. Immediately to the south, production has been established at Rockland and Sugar Creek fields in Jasper and Tyler Counties. Rockland field produced a small amount of oil $(45,000$ barrels) from Eocene Yegua sandstones, while Sugar. Creek is a small gas-condensate field producing from the Upper Cretaceous Woodbine Formation. Farther to the southeast the Turpentine field in Jasper County also produces a small amount of oil and gas from the Upper Cretaceous (Austin Group and Woodbine Formation). Rockland field discovered in 1928, is the oldest of these fields. A new field, McGee Bend, was discovered in Angelina County in 1982.

The resource potential of the area for oil and gas would be increased to a high potential if the domal shape of the Whitsett-Catahoula surface is structural and not erosional.

\section{Lignite}

There is no known lignite resource in the area. Kaiser and others (1980) inferred that a resource of near-surface lignite existed in the roadless area in the Manning Formation on the basis of sand content in the Manning. The shallow drilling program of this study indicates that there is no lignite in the upper 100-200 $\mathrm{ft}$ of the Manning Formation beneath the area. Although lignitic sand and silt are common in the Whitsett Formation, no lignite beds were penetrated in the auger holes.

\section{Clay}

Southern Angelina County and northern Jasper County have a considerable history of clay production from relatively small pits (less than 25 acres), one of which (now abandoned) is located within the area. Most production has been from the Whitsett Formation $1.5 \mathrm{mi}$ west of the area, although in January-February 1982 , only one pit was being mined. According to Fisher and others (1965), clay resources present in units of the Jackson Group, west and south of the roadless area, have the following special properties or uses: light firing, plastic kaolin, plastic smectite, naturally active bleaching clay, activated bleaching clay, swelling clay, drilling mud, lightweight aggregate clay, and high-alumina clay.

Kaolinite clay and smectite clay resources of limited extent are present in the roadless area (fig. 4). The boundaries of the resource areas drawn in figure 4 are very approximate and are based on data from exposures and auger holes. The kaolinite clay resource consists of quartzose silt in a monomineralic matrix of kaolinite clay. This is essentially the same material currently being mined west of the area. The kaolinite clay occurs in the southeast part of the area as a layer 5-20 ft thick, perhaps lenticular, in the top of the Whitsett Formation or in the base of the Catahoula.

The smectite clay resource in the north-central part of the area is greater than $15 \mathrm{ft}$ thick in auger hole 49 and is probably a lenticular body. It consists of quartzose silty smectite and occurs in the top of the Whitsett Formation.

\section{Uranium}

The Graham Creek Roadless Area was examined as part of the National Uranium Resource Evaluation (NURE) program (U.S. Department of Energy, 1979) to determine the uranium resources of the United States. Very low uranium values were found in groundwater samples and only slightly higher values were obtained from stream-sediment samples. Arfele (1980) also found very low uranium values in ground-water samples from the study area in an evaluation of uranium mineralization in the Whitsett Formation. In studies of uranium mineralization associated with the Catahoula Formation, Galloway (1977) and Ledger 


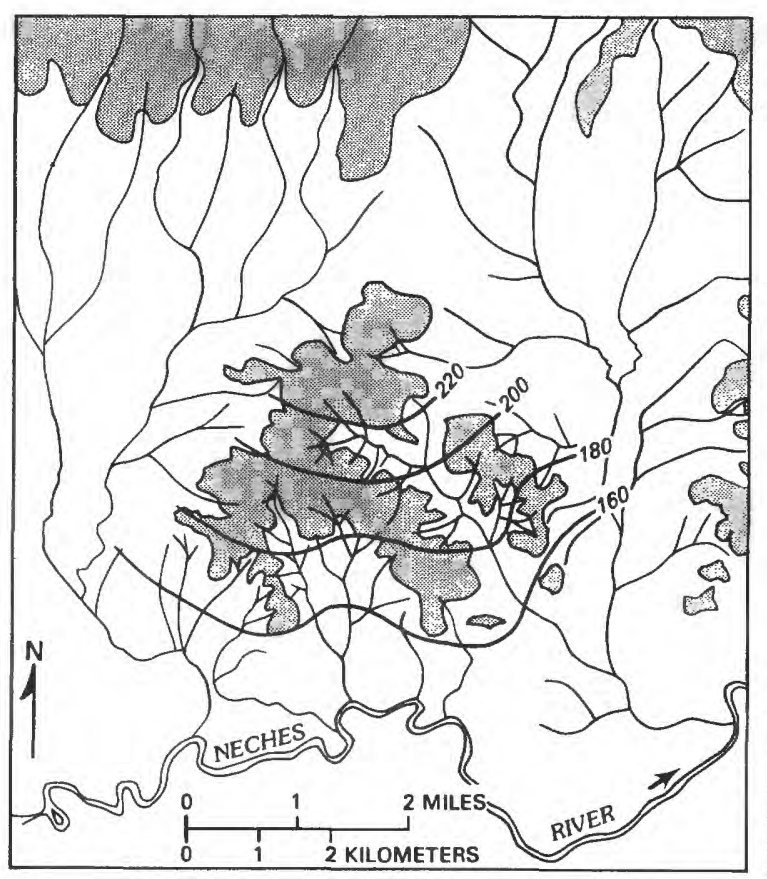

A EXPLANATION

Greater than 200 ft altitude

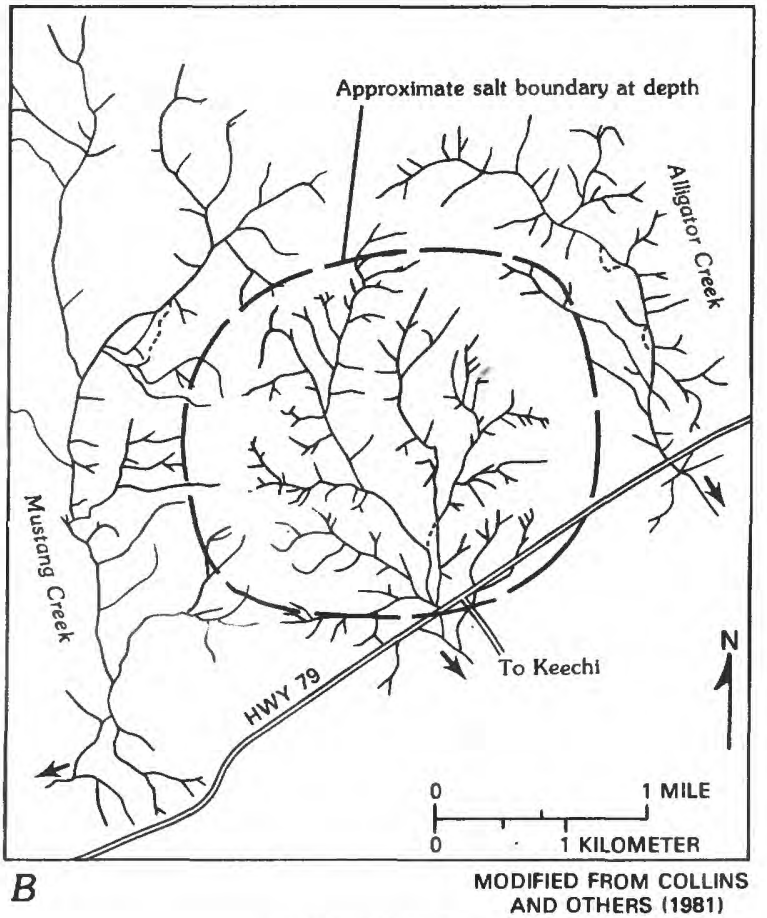

EXPLANATION

Cut-off channel

Figure 3.-Sketch maps showing similar shapes of drainage networks on $A$, the domal feature in the Graham Creek Roadless Area, and $\underline{B}$, the Oakwood salt dome. 




Geologic terrane with moderate to high resource potential for oil and gas

$/ \int$ Geologic terrane with kaolinite resource Geologic terrane with smectite resource

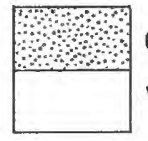

Catahoula Formation (Tertiary)

Whitsett and Manning Formations, undifferentiated (Eocene)

Contact

\footnotetext{
Oil or gas well

- Dry hole

\&- Abandoned well
}

Figure 4.-Map showing mineral resource potential of the Graham Creek Roadless Area, Texas. 
(1981) concluded that there is considerably less potential for the occurrence of uranium deposits in east Texas compared to south Texas.

In the present study, three samples of silty clay (two of them lignitic) from the Whitsett Formation, penetrated in auger hole 52, were analyzed for uranium. These samples contained 1.3, 1.1, and 1.1 ppm uranium. Three surface samples, one from the Whitsett and two from the Catahoula, contained 25, 10 , and $43 \mathrm{ppm}$ uranium, respectively. Although the surface samples may be above normal levels of uranium content, they are insufficient evidence to suggest other than a low potential for uranium in the area.

Sand

The basal sand of the Catahoula Formation is presently being mined and crushed $0.25 \mathrm{mi}$ east of the roadless area by the Neches Stone Company. Sand from the Catahoula was also mined from an abandoned sand pit in the southeast corner oi the area. The sand consists of a mixture of loose, slightly clayey sand and sharp fragments of opal-cemented sandstone and is used as road metal on the many graded roads of the region. Because of the local nature and lenticular shape of the opal-cemented sandstone bodies, it is not possible to predict their location or abundance; however, opal-cemented sandstone bodies undoubtedly exist at or near the base of the Catahoula within the roadless area because they are widespread throughout the outcrop belt of the Catahoula Formation.

Trace-element abundance

Thirty-seven auger samples of clay from the Manning and Whitsett Formations were analyzed spectrographically for 31 minor and trace elements. Table 1 shows the amounts of 14 trace elements present in clay from the Manning and Whitsett
Formations in comparison to the amounts of these elements present in chiefly fine-grained rocks of the Pierre Shale (Schultz and others, 1980). This comparison indicates that the trace-element composition of the clay in the roadless area is within the normal range for nonmineralized clay sediment, both marine and nonmarine,

Table 1.--Average trace-element determinations for 37 samples of clay from the Manning and Whitsett Formations and 202 samples from the Pierre Shale

Six-step D.C.-arc semiquantitative spectrographic analyses made in U.S. Geological Survey laboratories. Analysts, Betty Adrian and Belinda Arbogast. Determination for Pierre Shale samples from Shultz and others, 1980

\begin{tabular}{lccccc}
\hline & $\begin{array}{c}\text { Manning and Whitsett } \\
\text { Formations }\end{array}$ & & \multicolumn{2}{c}{ Pierre Shale } \\
\cline { 2 - 3 } \cline { 5 - 6 } & $\begin{array}{c}\text { Arithmetic } \\
\text { mean } \\
\text { (ppm) }\end{array}$ & $\begin{array}{c}\text { Standard } \\
\text { deviation } \\
\text { (ppm) }\end{array}$ & & $\begin{array}{c}\text { Arithmetic } \\
\text { mean } \\
\text { (ppm) }\end{array}$ & $\begin{array}{c}\text { Standard } \\
\text { deviation } \\
\text { (ppm) }\end{array}$ \\
\hline $\mathrm{Mn}$ & 285 & 198 & & 720 & 275 \\
$\mathrm{~B}$ & 156 & 57 & & 99 & 49 \\
$\mathrm{Ba}$ & 592 & 266 & & 650 & 300 \\
$\mathrm{Co}$ & 14 & 6 & & 12 & 6 \\
$\mathrm{Cr}$ & 82 & 34 & & 75 & 34 \\
$\mathrm{Cu}$ & 25 & 14 & & 34 & 23 \\
$\mathrm{La}$ & 76 & 26 & & 39 & 25 \\
$\mathrm{Ni}$ & 18 & 11 & & 36 & 27 \\
$\mathrm{~Pb}$ & 64 & 27 & & 22 & 8 \\
$\mathrm{Sc}$ & 13 & 4 & & 16 & 5 \\
$\mathrm{Sr}$ & 179 & 36 & & 204 & 204 \\
$\mathrm{~V}$ & 145 & 58 & & 156 & 97 \\
$\mathrm{Y}$ & 56 & 28 & & 28 & 12 \\
$\mathrm{Zr}$ & 300 & 199 & & 190 & 62 \\
\hline
\end{tabular}




\section{REFERENCES CITED}

American Petroleum Institute, American Gas Association, and Canadian Petroleum Association, 1980, Reserves of crude oil, natural gas liquids, and natural gas in the United States and Canada: New York, American Petroleum Institute, v. 34, $253 \mathrm{p}$.

Arfele, A. T., Jr., 1980, Uranium evaluation of the Whitsett Formation, East Texas: Nacogdoches, Texas, Stephen F. Austin State University Master's thesis, $51 \mathrm{p}$.

Barnes, V. E., 1968, Geologic atlas of Texas, Palestine $1^{\circ} \times 2^{\circ}$ quadrangle: University of Texas at Austin, Bureau of Economic Geology, scale $1: 250,000$.

Collins, E. W., Dix, O. R., and Hobday, D. K., 1981, Oakwood salt dome, East Texas-surface geology and drainage analysis: University of Texas at Austin, Bureau of Economic Geology Geological Circular 81-6, 23 p.

Cram, I. H., ed., 1971, Future petroleum provinces of the United States-their geology and potential: American Association of Petroleum Geologists Memoir 15, v. 2, p. 805-984.

Dickinson, K. A., 1976, Uranium potential of the Texas Coastal Plain: Geological Society of America Abstracts with Programs, v. 8, no. 1, p. 18.

Dodge, M. M., and Posey, J. S., 1981, Structural cross sections, Tertiary formations, Texas Gulf Coast: University of Texas at Austin, Bureau of Economic Geology, 6 p.

Fisher, W. L., 1965, Rock and mineral resources of East Texas, with contributions by, Chelf, C. R., Shelby, C. A., Garner, L. E., Owen, D. E., and Schofield, D. A.: University of Texas at Austin, Bureau of Economic Geology Report of Investigations $54,439 \mathrm{p}$.

Fisher, W. L., Proctor, C. V., Jr., Galloway, W. E., and Nagle, J. S., 1970, Depositional systems in the Jackson Group of Texas-their relationships to oil, gas, and uranium: Gulf Coast Association of Geological Societies Transactions, v. 20, p. 234261.

Galloway, W. E., 1977, Catahoula Formation of the Texas Coastal Plain--depositional systems, composition, structural development, groundwater flow history, and uranium distribution: University of Texas at Austin, Bureau of Economic Geology Report of Investigations 87, $59 \mathrm{p}$.

Garner, L. E., Pass, D. A., and West, E. S., 1978, Evaluation of lignite resources in the national forests of Texas: University of Texas at Austin,
Bureau of Economic Geology unpublished report prepared for the U.S. Forest Service contract no. 38-3145, 82 p.

International Oil Scouts Association, 1977, International Oil and Gas Development Yearbook 1977 (Review of 1976): Austin, Texas, International Oil Scouts Association, v. 47, pt. II, $352 \mathrm{p}$.

Kaiser, W. R., Ayers, W. B., Jr., and LaBrie, L. W., 1980, Lignite resources in Texas: University of Texas at Austin, Bureau of Economic Geology Report of Investigations $104,52 \mathrm{p}$.

Ledger, E. B., Jr., 1981, Evaluation of the Catahoula Formations as a source rock for uranium mineralization with emphasis on East Texas: College Station, Texas A \& M University $\mathrm{Ph}$. D. dissertation, $177 \mathrm{p}$.

McBride, E. F., Lindermann, W. L., and Freeman, P. S., 1968, Lithology and petrology of the Gueydan (Catahoula) Formation in South Texas: University of Texas at Austin, Bureau of Economic Geology Report of Investigations 63, $122 \mathrm{p}$.

Paine, W. R., and Meyerhoff, A. A., 1968, Catahoula Formation of western Louisiana and thin-section criteria for fluviatile depositional environment: Journal of Sedimentary Petrology, v. 38, p. 92113.

Peppard-Souders and Associates, 1981, Executive reference map' no. 302 for East Texas: Dallas, Geomap, scale $1: 187,500$.

1982, Executive reference map no. 312 for northeast Texas Gulf Coast: Dallas, Geomap, scale $1: 187,500$.

Scheldt, J. C., 1976, Petrology of the Catahoula sandstones in East Texas: Louisiana, University of New Orleans Master's thesis, $57 \mathrm{p}$.

Schultz, L. G., Tourtelot, H. A., Gill, J. R., and Boerngen, J. G., 1980, Composition and properties of the Pierre Shale and equivalent rocks, northern Great Plains region: U.S. Geological Survey Professional Paper 1064-B, $114 \mathrm{p}$.

St. Clair, A. E., Evans, T. J., and Garner, L. E., 1976, Energy resources of Texas: University of Texas at Austin, Bureau of Economic Geology map, scale $1: 1,000,000$

The Railroad Commission of Texas, 1981, Annual Report of the Oil and Gas Division: Austin, Texas, The Railroad Commission of Texas, $700 \mathrm{p}$.

U.S. Department of Energy, 1979, Hydrogeochemical and stream sediment basic data for Palestine NTMS quadrangle, Texas: National Uranium Resource Evaluation Project, GJBX-92 (79), 35 p. 


$$
1
$$

